\title{
Indole-3-Carbinol Derivative DIM Mitigates Carbon Tetrachloride-Induced Acute Liver Injury in Mice by Inhibiting Inflammatory Response, Apoptosis and Regulating Oxidative Stress
}

\author{
Suvesh Munakarmi ${ }^{1}$, Lokendra Chand ${ }^{1}$, Hyun Beak Shin ${ }^{2}$, Kyu Yun Jang ${ }^{3}[$ and \\ Yeon Jun Jeong ${ }^{1,2, *}$ \\ 1 Laboratory of Liver Regeneration, Biomedical Research Institute, Chonbuk National University Medical \\ School, Jeonju 54907, Korea; sanghzain@gmail.com (S.M.); chand_lb76@yahoo.com (L.C.) \\ 2 Department of Surgery, Chonbuk National University Hospital, Jeonju 54907, Korea; no1kal@naver.com \\ 3 Department of Pathology, Chonbuk National University Hospital, Jeonju 54907, Korea; \\ kyjang@chonbuk.ac.kr \\ * Correspondence: surgeon@chonbuk.ac.kr
}

Received: 22 February 2020; Accepted: 16 March 2020; Published: 17 March 2020

\begin{abstract}
Diindolylmethane (DIM), a metabolic product of indole-3-carbinol extracted from cruciferous vegetables exhibits anti-inflammatory and anti-cancer properties. Earlier, the product has been demonstrated to possess anti-fibrotic properties; however, its protective effects on liver injury have not been clearly elucidated. In this study, we postulated the effects and molecular mechanisms of action of DIM on carbon tetrachloride $\left(\mathrm{CCl}_{4}\right)$-induced liver injury in mice. Acute liver injury was induced by a single intraperitoneal administration of $\mathrm{CCl}_{4}(1 \mathrm{ml} / \mathrm{kg})$ into mice. DIM was injected via subcutaneous route for three days at various doses $(2.5,5$ and $10 \mathrm{mg} / \mathrm{kg})$ before $\mathrm{CCl}_{4}$ injection. Mice were sacrificed and serum was collected for quantification of serum transaminases. The liver was collected and weighed. Treatment with DIM significantly reduced serum transaminases levels (AST and ALT), tumor necrosis factor- $\alpha$ (TNF- $\alpha$ ) and reactive oxygen species (ROS). $\mathrm{CCl}_{4}$ - induced apoptosis was inhibited by DIM treatment by the reduction in the levels of cleaved caspase- 3 and Bcl2 associated X protein (Bax). DIM treated mice significantly restored Cytochrome P450 2E1, nuclear factor erythroid 2-related factor 2 (Nrf2) and heme oxygenase-1 (HO-1) expression in $\mathrm{CCl}_{4}$ treated mice. In addition, DIM downregulated overexpression of hepatic nuclear factor kappa B (NF-kB) and inhibited $\mathrm{CCl}_{4}$ mediated apoptosis. Our results suggest that the protective effects of DIM against $\mathrm{CCl}_{4}$ - induced liver injury are due to the inhibition of ROS, reduction of pro-inflammatory mediators and apoptosis.
\end{abstract}

Keywords: DIM; carbon tetrachloride $\left(\mathrm{CCl}_{4}\right)$; nuclear factor erythroid-2-related factor 2 (Nrf2); hemeoxygenase-1 (HO-1); inflammation; apoptosis; oxidative stress

\section{Introduction}

The liver, a vital organ, acts as an accessory digestive gland that produces biochemicals necessary for digestion, detoxifies various metabolites and synthesizes proteins. Therefore, pathogenesis in the liver rises due to the involvement of numerous cytokines and growth-factor-mediators [1]. Depending upon the characteristics, liver injuries are reversible and are mostly self-healing [2]. However, the progression of repeated injury and rapid dysfunction of liver can lead to multi-organ failure and even death [3]. Liver injury can be acute or chronic resulting from multiple reasons such as viral 
hepatitis, drug overdose, idiosyncratic drug reaction and toxins [4]. To date, the characteristics of liver injury have been explored extensively, but no effective therapeutic steps have been implemented $[5,6]$.

Oxidative stress and inflammation are considered as a common pathological mechanism to be involved in the initiation and progression of liver injury $[7,8]$. Both enzymatic antioxidants such as superoxide dismutase (SOD) and catalase (CAT) and non-enzymatic antioxidants such reduced glutathione (GSH) are important for cellular response and are used as indexes to evaluates the level of oxidative stress [9-11]. Nrf2/HO-1 cascade has found to be a protective master regulator against liver disease through the means of cellular defense by mediating antioxidant response and anti-inflammatory and cytoprotective properties. Loss or dysregulation of Nrf2/HO-1 activity was found to be correlated with the development of chronic inflammatory diseases [12-16]. Therefore, antioxidant and anti-inflammatory therapies are proposed to prevent and treat liver injury.

Carbon tetrachloride $\left(\mathrm{CCl}_{4}\right)$ is a well-characterized drug used to induce hepatic injury widely in scientific research [17]. $\mathrm{CCl}_{4}$ is believed to be involved in inducing multiple phases of liver injury. The first event of liver injury is the disruption in the permeability of plasma, lysosomes, and mitochondrial membrane [18]. Formation of highly reactive free radicals by the metabolic activity of liver enzyme Cytochrome P450 2E1 (CYP2E1) to trichloromethyl radical $\left(\mathrm{CCl}_{3}^{*}\right)$ leads to oxidative degradation of lipids [19]. The second event of $\mathrm{CCl}_{4}$ induced liver injury involves the formation of pro-inflammatory cytokines such as Tumor necrosis factor (TNF- $\alpha$ ) that stimulate Kupffer cells, thereby resulting in the production of pro-inflammatory mediators [20]. Production of the cytokines leads to apoptosis of hepatocytes and liver inflammation [21]. The formation of inflammatory cytokines increases reactive oxygen species (ROS) generation along with the stimulation of oxidative stress with consequent advancement of liver injury [22]. Consequently, the blocking of various inflammatory pathways and inhibiting oxidative stress provides an effective aid to heal liver injury.

3,3'-diindolylmethane (DIM) is a major bioactive precursor of Indole-3-carbinol extracted from cruciferous vegetables such as broccoli, Brussels sprouts, cabbage and kale [23]. Previous studies reported that DIM has numerous preventive roles, including anti-inflammatory, free radical scavenging, anti-oxidant and anti-cancer effects [24]. Recent studies have noted the protective effect of DIM against liver injury, cardiac-inflammatory responses and renal fibrosis. S Tomar et al. reported that DIM inhibits lipopolysaccharide (LPS)-mediated liver injury by targeting Interleukin-1 Receptor-Associated Kinase 4 (IRAK4) and modulating Toll-like receptor signaling [25]. Luo et al. reported that DIM attenuates LPS-induced inflammatory responses and apoptosis in cardiomyopathy [24]. Additionally, DIM inhibited fibrosis by inhibiting TGF $\beta / \mathrm{Smad} 2 / 3$ signaling pathways [26]. However, the protective effects of DIM in CCl4 induced liver injury remain unclear. Therefore, we aim to explore the potential therapeutic effects and mechanism of action of DIM in the case of $\mathrm{CCl}_{4}$-induced liver injury.

\section{Results}

\subsection{DIM Inhibits $\mathrm{CCl}_{4}$ Induced Liver Injury}

Analysis of serum AST and serum ALT is an essential biochemical analysis for determining liver function. The effect of DIM on the serum AST, ALT levels and protein expression of CYP2E1 in $\mathrm{CCl}_{4}$-treated mice is shown in Figure $1 \mathrm{~A}-\mathrm{C}$. $\mathrm{CCl}_{4}$ treatment gradually increased the activities of serum AST and ALT and dramatically decreased CYP2E1 expression. However, pretreatment with DIM and silymarin remarkably decreased the AST, ALT levels and restored the expression of CYP2E1 in $\mathrm{CCl}_{4}$-treated mice. These results illustrate that DIM significantly reverses the effects of $\mathrm{CCl}_{4}$ in a dose-dependent manner. 
A

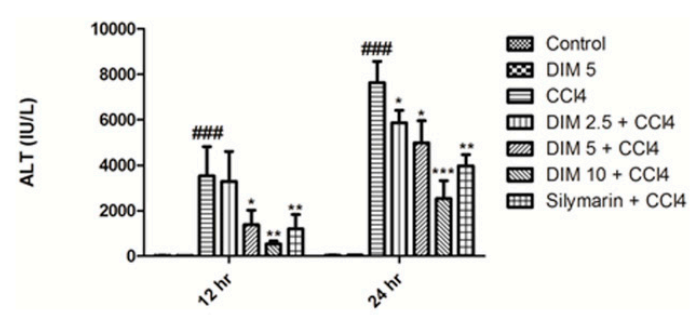

C

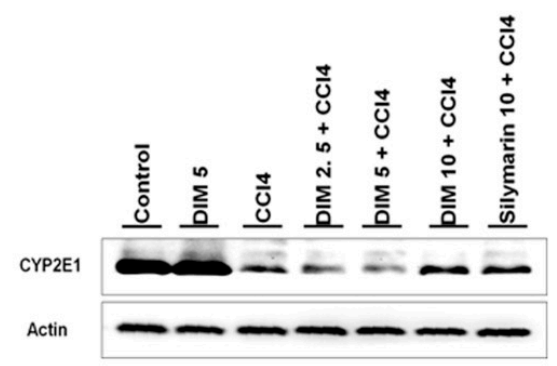

B

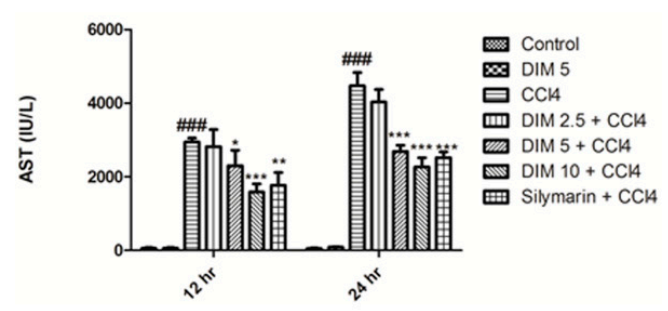

D

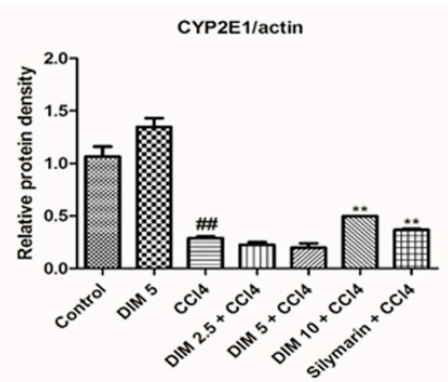

Figure 1. Effects of 3,3'-diindolylmethane (DIM) on serum levels of alanine aminotransferase (ALT, A) and aspartate aminotransferase (AST, B) at 12 and $24 \mathrm{~h}$ after $\mathrm{CCl}_{4}$ administration. Data are expressed as mean \pm SD $(n=5)$. (C) Immunoblot analysis of Cytochrome P450 2E1 (CYP2E1) at $24 \mathrm{~h}$ after $\mathrm{CCl}_{4}$ injection. (D) Quantification of relative protein expression normalized to $\beta$-actin. Data are expressed as mean $\pm \operatorname{SD}(n=3)$. ${ }^{\# \# \#} p<0.001$ and ${ }^{\# \#} p<0.01$ denotes significant differences compared to the normal control group, ${ }^{*} p<0.05,{ }^{* *} p<0.01,{ }^{* * *} p<0.001$ compared to the $\mathrm{CCl}_{4}$ group.

\subsection{DIM Mitigates $\mathrm{CCl}_{4}$-Induced Hepatic Histopathological Damage}

Figure 2 shows the extent of histopathological damage as examined by H\&E staining in liver sections. Histopathological feature of $\mathrm{CCl}_{4}$-induced liver injury was characterized based on shrinkage of nuclei, multiple area of portal inflammation and massive hepatocyte necrosis, which were significantly attenuated by pretreatment with $\operatorname{DIM}(2.5,5 \mathrm{and} 10 \mathrm{mg} / \mathrm{kg})$ and silymarin $(10 \mathrm{mg} / \mathrm{kg})$ in a dose-dependent manner (Figure 2A,B and Figure S1). 
A

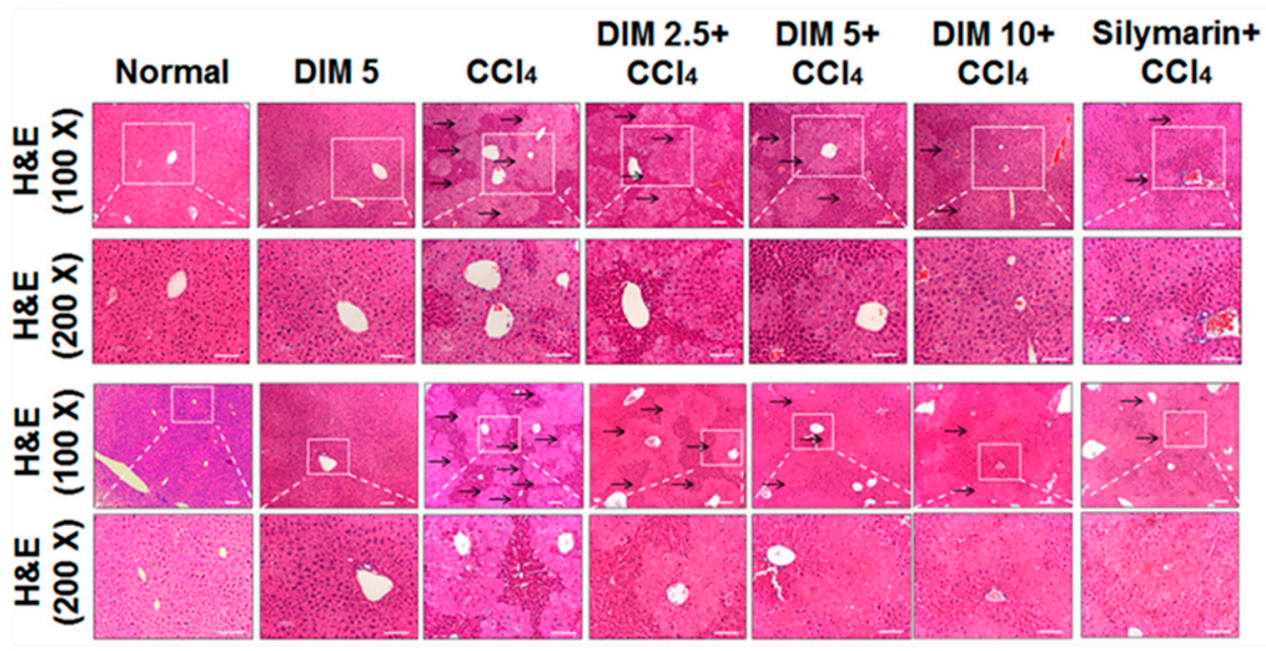

$12 \mathrm{~h}$

$24 \mathrm{~h}$

B

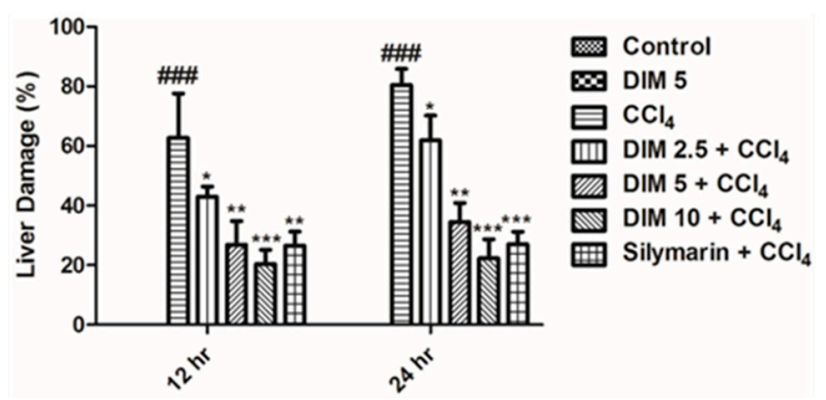

Figure 2. Effects of DIM on histopathological changes of liver tissues; the black arrow shows the necrotic area and liver damage (A) and the quantitative measurement (\%) area of damage (B) of liver tissues after $\mathrm{CCl}_{4}$ injection. The tissues were stained with $\mathrm{H} \& \mathrm{E}$. The liver sections were observed at X100 and X200 magnification. The scale bar represents 50 and $100 \mu \mathrm{m}$, respectively. Data are expressed as mean $\pm \mathrm{SD}(n=5)$. \#\#\# $p<0.001$ denotes significant differences compared to the normal control group, ${ }^{*} p<0.05,{ }^{* *} p<0.01,{ }^{* * *} p<0.001$ denotes significant difference compared to the $\mathrm{CCl}_{4}$ group.

2.3. DIM Pretreatment Inhibits $\mathrm{CCl}_{4}$-Induced Oxidative Stress and ROS Production in Response to $\mathrm{CCl}_{4}$ Administration

The generation of reactive oxygen species and increased lipid peroxidation are considered as important factors for the determination of chemically induced liver injury in mice. To determine the protective effects of DIM on $\mathrm{CCl}_{4}$-induced oxidative stress, the intensity of ROS production and the levels of MDA, in the liver were examined as shown in Figure 3. In comparison with the control group, mice from $\mathrm{CCl}_{4}$ injury groups showed significantly increased intensity of red fluorescence ROS and elevated MDA levels and as shown in (Figure 3A,B). DIM pretreatment significantly attenuated the level of oxidative stress marker and MDA and lowered the DHE fluorescence, suggesting that DIM probably inhibits $\mathrm{CCl}_{4}$-induced hepatic damage by reducing oxidative stress and inhibiting the production of ROS in a-dose-dependent manner. 
A

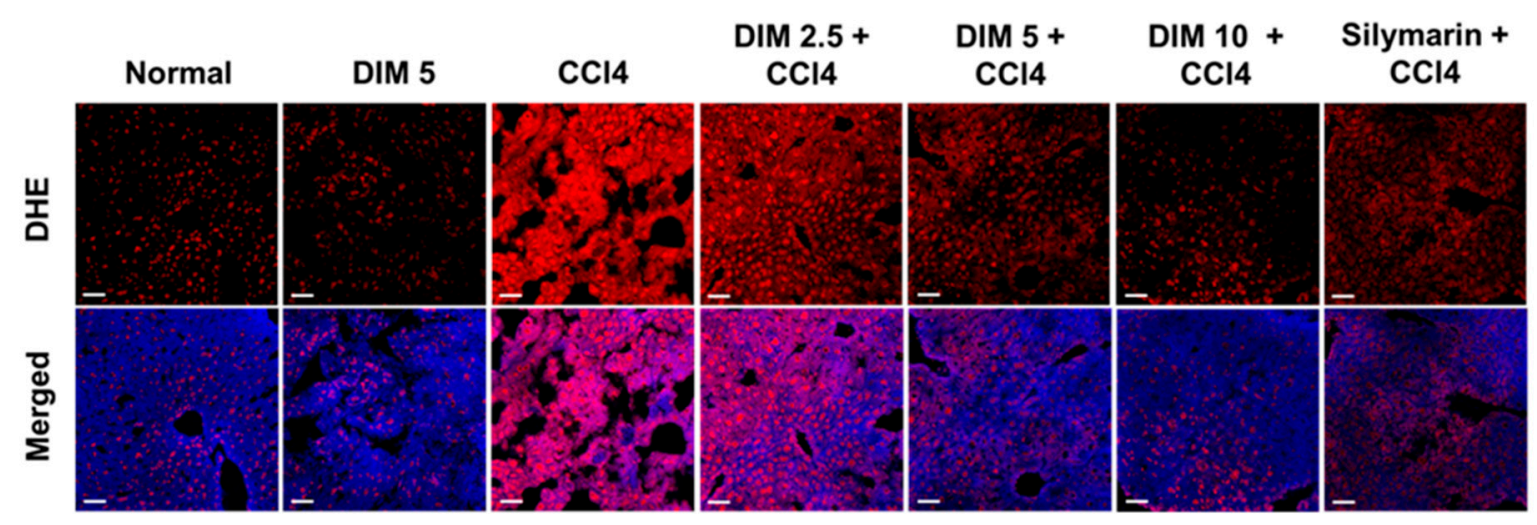

B

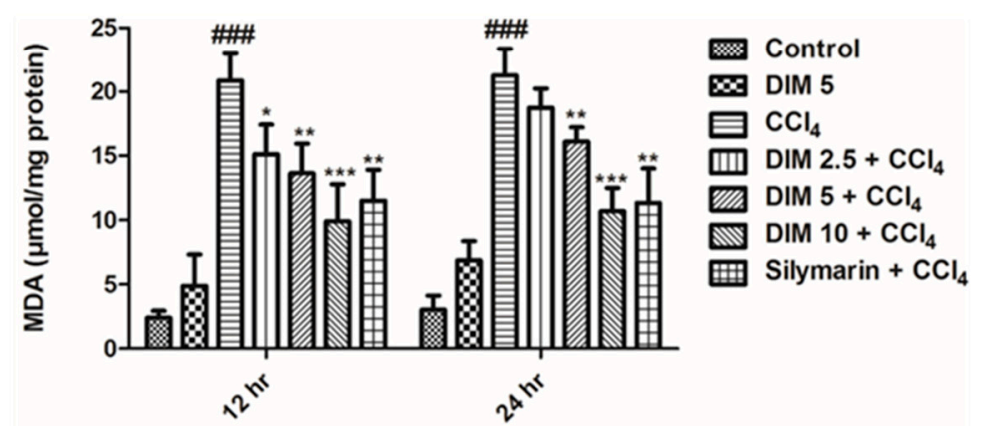

Figure 3. DIM pretreatment attenuates $\mathrm{CCl}_{4}$-induced oxidative stress and $\mathrm{ROS}$ production in mice. (A) Cryostat liver sections were treated with $5 \mu \mathrm{M}$ (DHE) dihydroethidium at $37^{\circ} \mathrm{C}$ for $30 \mathrm{~min}$, washed with PBS and mounted with DAPI and assessed using a confocal microscope. The scale bar represents $30 \mu \mathrm{m}$. (B) MDA levels were measured using a commercial kit. Data are presented as mean $\pm \operatorname{SD}(n=5)$. \#\#\# $p<0.001$ determined as significant differences compared to the normal control group, ${ }^{*} p<0.05$, ** $p<0.01,{ }^{* * *} p<0.001$ compared to the $\mathrm{CCl}_{4}$ group.

2.4. DIM Pre-Treatment Modulates Antioxidant Activity by Regulating the Nrf2/HO-1 Signaling Pathway and Inhibits Oxidative Stress in Response to $\mathrm{CCl}_{4}$ Administration

Previous studies elucidate that the Nrf2/HO-1 signaling pathway plays an important role in $\mathrm{CCl}_{4}$-induced liver injury by inhibiting oxidative stress. Furthermore, to analyze the molecular mechanism underlying the protective effect of DIM against $\mathrm{CCl}_{4}$-induced oxidative injury, we measured the levels of reduced GSH and SOD activity as shown in Figure 4A,B, whereas protein levels of $\mathrm{Cu} / \mathrm{Zn}$ SOD, Nrf2 and its target genes were measured by Western blot analysis (Figure 4C). DIM pretreatment significantly improved the levels of endogenous antioxidant such as reduced GSH and SOD and induced the protein levels of Nrf2, HO-1, and $\mathrm{Cu} / \mathrm{Zn}$ SOD. These results suggest that DIM enhances the antioxidant ability through $\mathrm{Nrf} 2 / \mathrm{HO}-1$ activation and inhibits oxidative stress. 
A

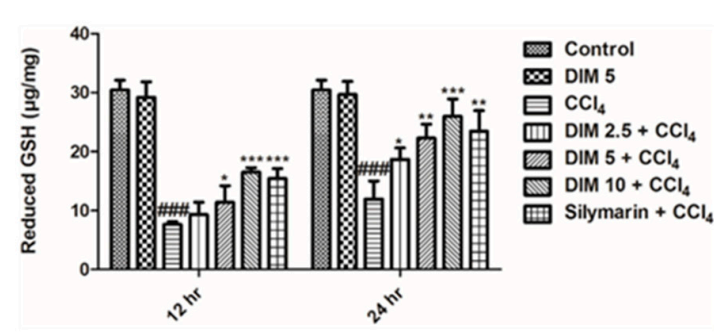

C

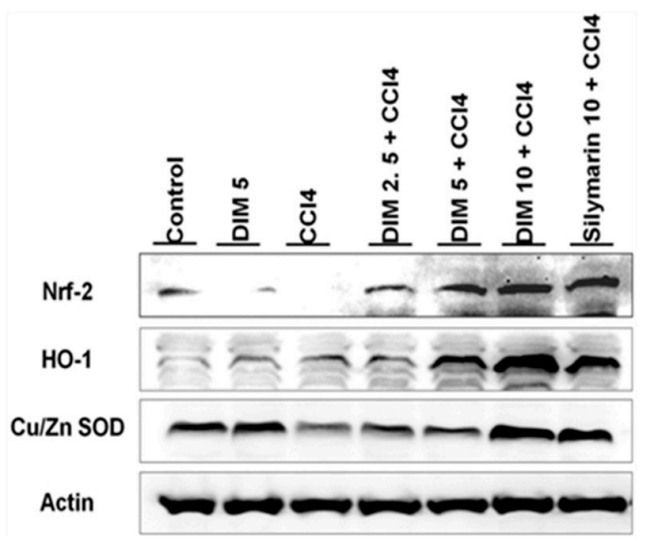

B

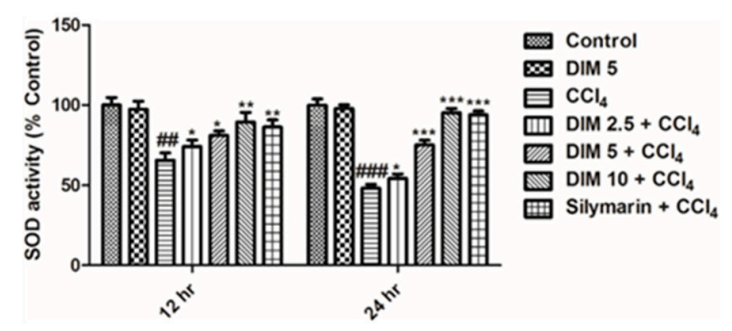

D
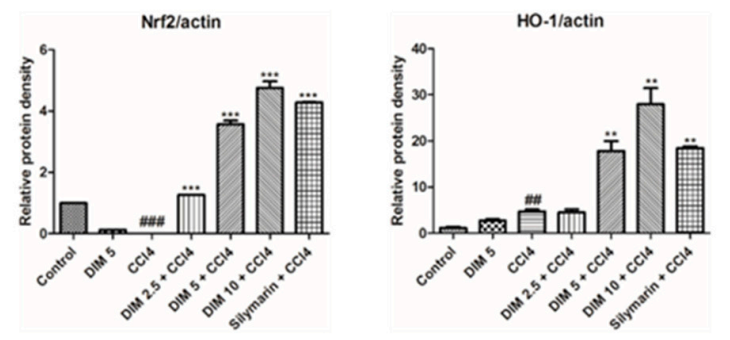

CuZnSoD/actin

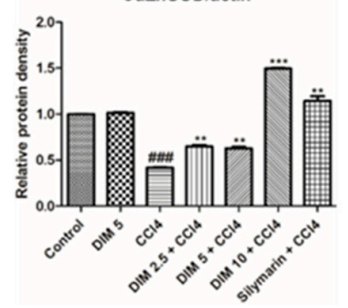

Figure 4. DIM increased detoxification and improved antioxidant ability by regulating the Nrf2/HO-1 signaling pathway and inhibiting oxidative stress in $\mathrm{CCl}_{4}$-induced liver injury in mice. (A) Reduced glutathione (GSH); (B) superoxide dismutase (SOD) activity; data are expressed as mean $\pm \mathrm{SD}(n=5)$. (C) Protein expression of Nrf2, $\mathrm{HO}-1$, and $\mathrm{Cu} / \mathrm{Zn} \mathrm{SOD}$ at $24 \mathrm{~h}$ after $\mathrm{CCl}_{4}$ injection by using Western blot analysis. (D) Quantification of relative protein expression normalized to $\beta$-actin. Data are expressed as mean $\pm \operatorname{SD}(n=3)$. ${ }^{\# \# \#} p<0.001$ and ${ }^{\# \#} p<0.01$ denotes significant differences compared to the normal control group, ${ }^{*} p<0.05,{ }^{* *} p<0.01,{ }^{* * *} p<0.001$ compared to the $\mathrm{CCl}_{4}$ group.

\subsection{DIM Pre-Treatment Inhibits $\mathrm{CCl}_{4}$-Induced Inflammatory Mediators and Cytokines}

Inflammatory response plays a key role in the progression of liver damage. To reveal the mechanisms by which DIM inhibits inflammatory response induced by $\mathrm{CCl}_{4}$, Western blot analysis, and enzymatic assay were performed. As shown in Figure 5, the protein expression of three important inflammatory cytokines (TNF- $\alpha$, IL-6, IL-1 $\beta$ ) and serum TNF- $\alpha$ were significantly increased in the $\mathrm{CCl}_{4}$ group. However, pretreatment of DIM inhibited these elevations. Cyclooxygenase-2 (COX-2) and inducible nitric oxide synthase (iNOS) are two important enzymes known as key executors of uncontrolled inflammation by producing prostaglandin and NO, respectively. Pretreatment of DIM significantly suppressed hepatic COX-2 and iNOS expression levels induced by $\mathrm{CCl}_{4}$ administration. These findings suggest that DIM protects the liver from injury by inhibiting the production of inflammatory cytokines and mediators. 
A

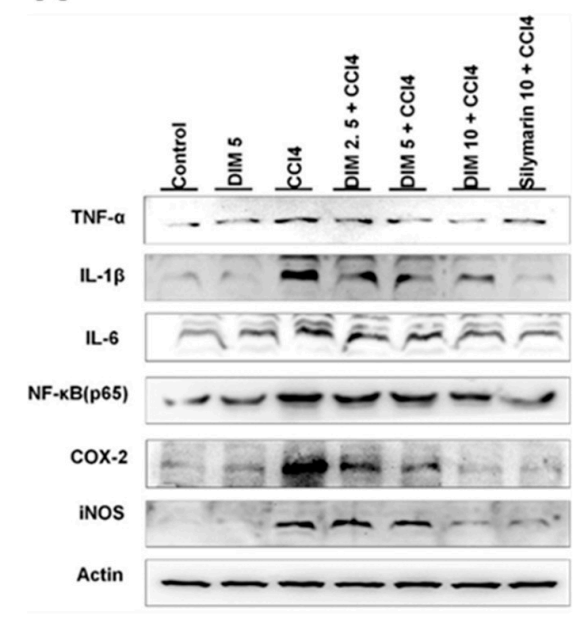

C

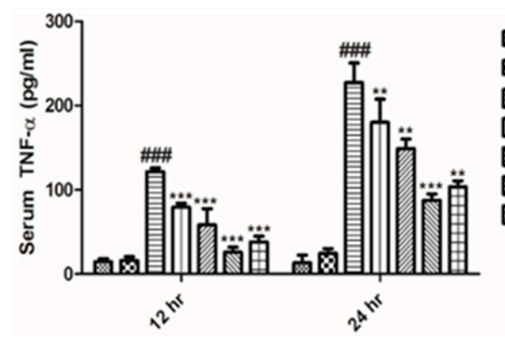

B
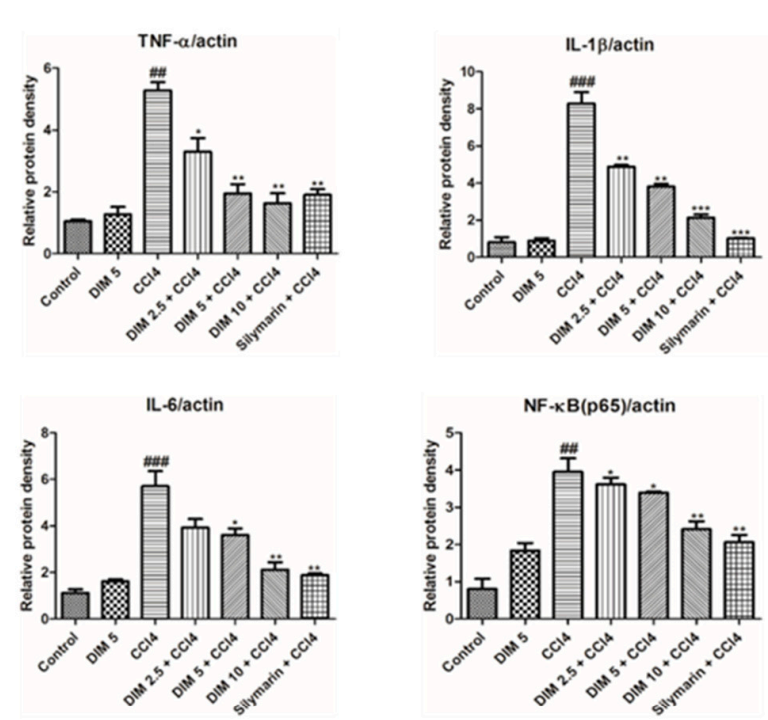

iNOS/actin
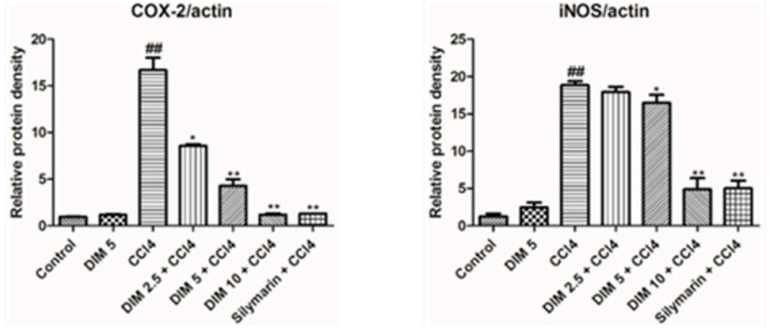

Figure 5. DIM pretreatment inhibits the protein expression levels of inflammatory factors in liver tissue of $\mathrm{CCl}_{4}$-induced liver injury in mice. (A) Protein expression of pro-inflammatory cytokines (TNF- $\alpha$, IL-6 IL-1 $\beta$ ) and inflammatory mediators (COX-2 and iNOS) at $24 \mathrm{~h}$ after $\mathrm{CCl}_{4}$ injection by using Western blot analysis. (B) Quantification of relative protein expression normalized to $\beta$-actin. (C) The level of serum TNF- $\alpha$ measured using ELISA kits. The values represent the mean \pm SD $(n=3)$. \#\#\# $p<0.001$ and ${ }^{\# \#} p<0.01$ denotes significant differences compared to the normal control group, ${ }^{*} p<0.05,{ }^{* *} p<0.01,{ }^{* * *} p<0.001$ compared to the $\mathrm{CCl}_{4}$ group.

\subsection{DIM Pre-Treatments Attenuates $\mathrm{CCl}_{4}$-Induced Hepatocyte Apoptosis in Mice}

In order to determine the hepatoprotective effect of DIM against $\mathrm{CCl}_{4}$-induced apoptosis, the levels of various apoptotic and anti-apoptotic markers were analyzed by Western blot. As shown in Figure 6, $\mathrm{CCl}_{4}$ administration significantly decreases the expression of the anti-apoptotic protein, $\mathrm{Bcl} 2$, while increasing the expression of the pro-apoptotic protein, Bax. However, these expressions were reversed with DIM pretreatment. Activation of caspase plays an important role in apoptosis; $\mathrm{CCl}_{4}$ administration remarkably increased the cleavage of caspase- 3 and caspase-9, suggesting severe apoptosis, while these elevations were attenuated by pretreatment with DIM. These results suggest that DIM imparts a protective effect against $\mathrm{CCl}_{4}$-induced liver injury by suppressing apoptotic response. 
A

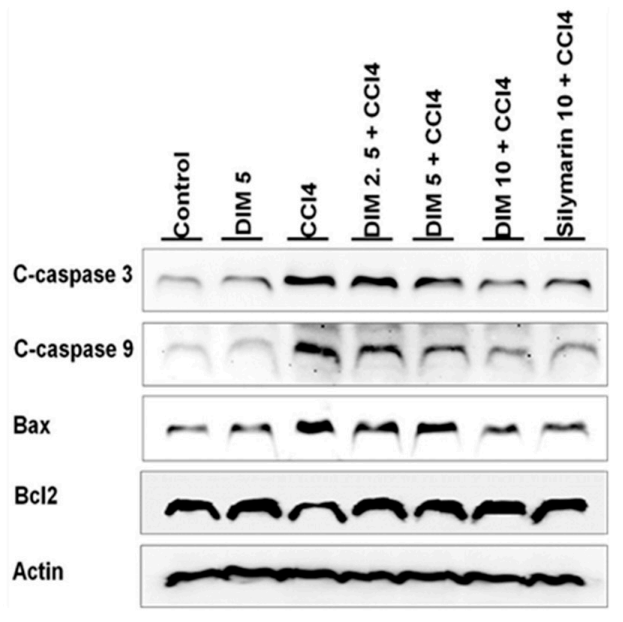

B
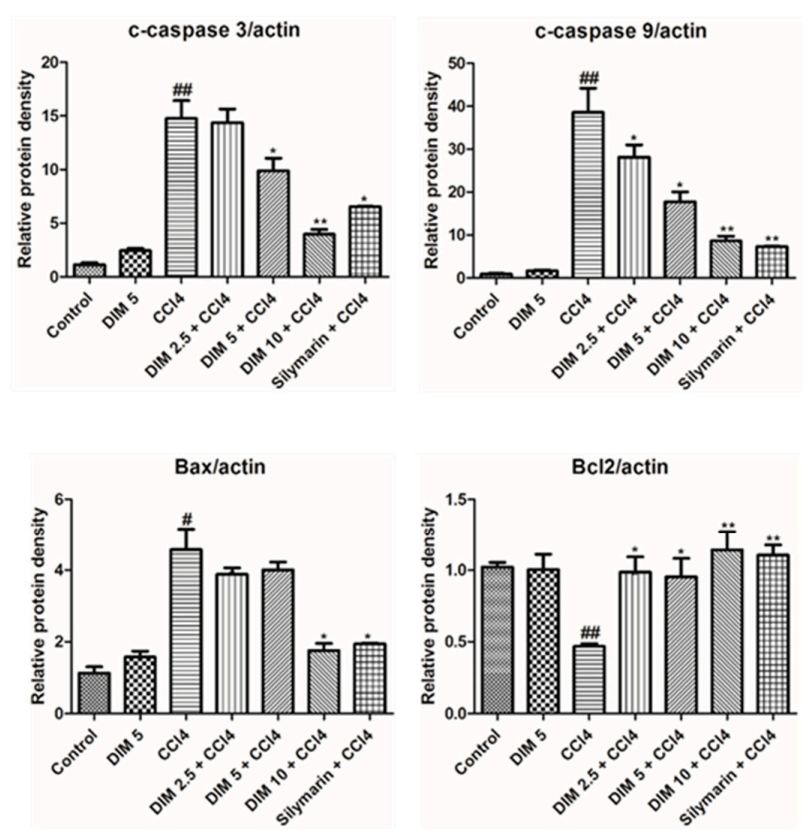

Figure 6. Pretreatment of DIM inhibits $\mathrm{CCl}_{4}$-induced hepatic cell death. (A) Western blot analysis showing the expression of apoptotic proteins (cleaved caspase-3, cleaved caspase-9); pro-apoptotic proteins Bax and anti-apoptotic protein Bcl2 at $24 \mathrm{~h}$ after $\mathrm{CCl}_{4}$ injection. (B) Quantification of relative protein expression normalized to $\beta$-actin. The values represent the mean $\pm \operatorname{SD}(n=3)$. ${ }^{\#} p<0.05$ and \#\# $p<0.01$ denoted significant differences compared to the normal control group, ${ }^{*} p<0.05,{ }^{* *} p<0.01$, *** $p<0.001$ compared to the $\mathrm{CCl}_{4}$ group.

\section{Discussion}

The Liver is one of the important vital organs that helps in maintaining various metabolic activities and functions of the body. Any injury to the liver leads to oxidative stress and inflammation [27]. $\mathrm{CCl}_{4}$-induced liver injury is the most commonly used experimental model to evaluate the hepato-protective effect of natural products [28]. There are many side effects of Western medicines that have been reported for the treatment of liver injury [29]. Therefore, natural medicines have become a future potential therapeutic hope for controlling liver disease. Although several studies have reported anti-inflammatory, anti-cancer and antioxidant effects of DIM [26,30], the molecular mechanism and regulation of DIM in the suppression of inflammatory response, inhibition ROS-induced lipid peroxidation and apoptosis in $\mathrm{CCl}_{4}$-induced liver injury remain unknown. In the present study, we attempt to determine the antioxidative, anti-inflammatory and apoptotic effects of DIM in $\mathrm{CCl}_{4}-$ induced liver injury.

Elevated levels of serum AST and serum ALT are the major indices of $\mathrm{CCl}_{4}$-induced liver toxicity with damage in the cell membrane and loss of functional integrity of hepatocytes [31]. The toxicity of $\mathrm{CCl}_{4}$ often results in the formation of free radical trichloromethyl in the liver by cytochrome $\mathrm{P} 450$ enzyme (CYP2E1) in the endoplasmic reticulum of hepatocytes thereby causing severe liver damage [32]. However, some studies found that $\mathrm{CCl}_{4}$ inhibits the expression of CYP2E1 due to the labilization and inactivation caused by ongoing oxidative and apoptosis [33-35]. Previous studies stated that $\mathrm{CCl}_{4}$ dramatically increased the serum ALT and AST levels and led to changes in the membrane integrity of hepatocytes in mice [36,37]. In the current study, pretreatment of DIM significantly lowered the levels of liver enzymes (parameters of liver injury) and potentially stabilized the hepatic histological changes by decreasing hepatic damage in dose and time-dependent manner, suggesting that DIM may serve as a novel approach for the treatment of $\mathrm{CCl}_{4}$-induced liver injury in mice. 
The end product of lipid peroxidation is MDA, which is considered as an indicator of ROS for measuring oxidative stress induced by $\mathrm{CCl}_{4}$ injury. $[38,39]$. In order to validate the hepatoprotective and antioxidant ability of DIM, endogenous levels of antioxidant enzymes such as superoxide dismutase (SOD) and reduced glutathione (GSH) were measured. SOD and reduced GSH are the first lines of the antioxidative defense system. SOD is important for the conversion of superoxide radicals into $\mathrm{H}_{2} \mathrm{O}_{2}$ and $\mathrm{O}_{2}$ whereas reduced GSH is important in catalyzing the reduction of hydrogen peroxide and preventing them from the free radical formation. [40,41]. The findings of this research are consistent with previous studies that show ROS after $\mathrm{CCl}_{4}$ treatment inactivated the antioxidant enzymes SOD and reduced GSH [42]. Our data showed that DIM effectively decreased reduced GSH and restored enzymes SOD and also attenuated MDA levels in time and dose-dependent manner.

Nrf2 is a known redox-responsive transcription factor that plays an important role in regulating antioxidant response elements (AREs) and thereby regulates the expression of a battery of genes, such as HO-1, GST, GCLC and GCLM [43-45]. Previously, numerous studies have proven the importance of antioxidants against hepatic injury by triggering the Nrf2/HO-1 signaling pathway [46,47]. Quite a few studies have reported that $\mathrm{Nrf2}$ was involved in protection against $\mathrm{CCl}_{4}$-induced liver injury $[48,49]$. $\mathrm{Nrf2}$ plays a key role in regulating the antioxidant defense system in response to $\mathrm{CCl}_{4}$ induced oxidative stress, and activation of $\mathrm{Nrf} 2$ is considered as a strong antioxidant and protection against liver injury $[50,51]$. Consistent with other studies, we found that $\mathrm{CCl}_{4}$ noticeably decreased protein levels of Nrf2 and increased HO-1 expression, while DIM pretreatment restored the expression of these proteins thereby indicating that DIM exhibits protective against $\mathrm{CCl}_{4}$-induced liver injury by activating Nrf2/HO-1 signaling pathway.

Elicitation of inflammation response plays a crucial role in the pathological process of $\mathrm{CCl}_{4}$-induced liver injury $[52,53]$. Previous studies have shown that the expression of pro-inflammatory cytokines (TNF- $\alpha$, IL-6, IL-1 $\beta$ ) and inflammatory mediators (COX-2 and iNOS) plays important role in the development and maintenance of inflammation related to liver injury [19,54-56]. iNOS is responsible for the production $\mathrm{NO}$, which is a highly reactive molecule synthesized from L-arginine. Overproduction of $\mathrm{NO}$ is one of the causes of inflammatory responses by inhibiting the growth of lymphocytes and damaging surrounding cells and tissues $[53,57]$. In this study, the expression of IL-6, IL-1 $\beta$, COX-2, iNOS, and TNF- $\alpha$ in both the serum and liver were substantially increased by $\mathrm{CCl}_{4}$ thereby leading to liver damage, which was inhibited by DIM pre-treatment. These results suggested that DIM exhibits an anti-inflammatory effect by suppressing the inflammatory response induced by $\mathrm{CCl}_{4}$.

Apoptosis and necrosis play an important role to contribute in the progression of liver injury [58,59], but it is still unclear whether necrosis or apoptosis is dominant in $\mathrm{CCl}_{4}$-induced liver injury [60]. The previous study revealed that $\mathrm{CCl}_{4}$-induced acute liver damage is characterized by necrotic cell death [58], while another study suggested the involvement of $\mathrm{CCl}_{4}$-induced hepatic cell apoptosis [60]. In our study, the $\mathrm{CCl}_{4}$-induced hepatic injury model followed the apoptotic pathway where caspase activation was involved. Several pro-apoptotic and anti-apoptotic proteins such as Bax and Bcl2 are responsible for cellular apoptosis [61-64]. Bax is an important pro-apoptotic gene in the Bcl2 family, which may translocate to the mitochondria to induce apoptosis [65], whereas $\mathrm{Bcl} 2$ is an anti-apoptotic protein that suppresses apoptosis $[66,67]$. In our study, we found that $\mathrm{CCl}_{4}$ administration induced apoptosis of liver cells by significant elevation of cleaved caspase-3, cleaved caspase- 9 and Bax expression while Bcl2 expression was inhibited, and these conditions were reversed in DIM pretreatment condition. These results reveal the protective effect of DIM involving alleviation $\mathrm{CCl}_{4}$-induced liver injury by inhibition of apoptosis.

\section{Materials and Methods}

\subsection{Chemical and Reagents}

DIM (purity $>98 \%$ ) and $\mathrm{CCl}_{4}$ were purchased from Sigma-Aldrich Chemical Co., St. Louis, $\mathrm{MO}$, USA. serum alanine transaminase (ALT) and aspartate transaminase (AST) assay kits were purchased 
from Asam Pharm. Co. Ltd., South Korea. TNF- $\alpha$ Elisa kits were purchased from Koma Biotech (Seoul, Korea). Glutathione (GSH) and malondialdehyde (MDA) were purchased from Biovision (S Militas Blvd., CV, USA) and Cell Biolabs (San Diego, CA, USA) respectively. DHE (dihydroethidium) was purchased from Invitrogen (Carlsbad, CA, USA).

\subsection{Experimental Animals}

Specific pathogen-free male FVB mice (6-8 weeks old) were purchased from Koatech (Pyeongtake, Korea). All mice were housed and given libitum access to food and water. All experimental procedures were conducted according to the ethical guidelines, and the protocols were approved by the Institutional Animal Care and Use Committee of Chonbuk National University, Jeonju, South Korea (Approved no: CBNU 2019-030).

\subsection{Animal Model and Treatment with DIM}

All mice were randomly divided into 12 and $24 \mathrm{~h}$ sets with seven groups of 5 mice in each set. Group I (control group) and group III (negative control) mice were injected with normal saline for 3 consecutive days. Group II (DIM only group) mice were treated with $5 \mathrm{mg} / \mathrm{kg}$ DIM, and group VII (positive control group) were subcutaneously (sub-q) treated with silymarin $(10 \mathrm{mg} / \mathrm{kg})$ for three days. Group IV-VI (DIM $+\mathrm{CCl}_{4}$ group) mice received (sub-q) 2.5, 5 and $10 \mathrm{mg} / \mathrm{kg}$ of DIM dissolved in PBS for three consecutive days. On the third day, $1 \mathrm{~h}$ after the last administration, all groups except groups I and II were injected with a single dose of $\mathrm{CCl}_{4}(10 \%$ in mineral oil), whereas animals in groups I and II were i.p. injected with mineral oil. Mice from each group were anesthetized and sacrificed at 12 and $24 \mathrm{~h}$ of $\mathrm{CCl}_{4}$ injection as shown in Figure 7, and samples of blood and liver tissues were collected for further analysis.

A

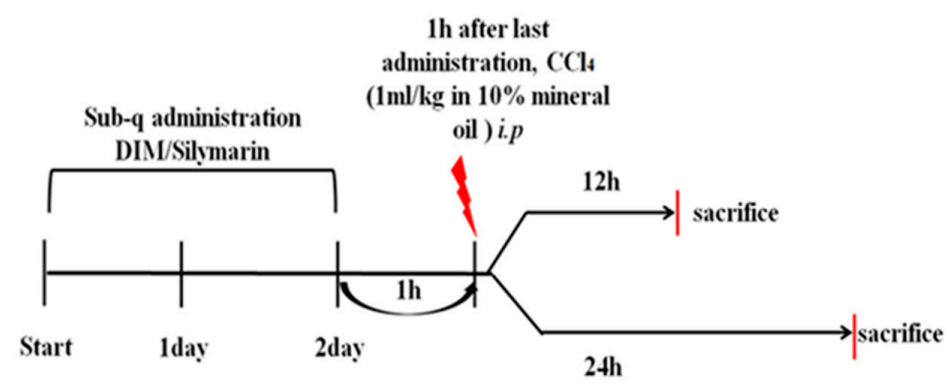

B

\begin{tabular}{|c|c|c|}
\hline No. & \multicolumn{2}{|c|}{ Group } \\
\hline 1 & Control & Normal saline \\
\hline 2 & DIM only & DIM 5mg/kg \\
\hline 3 & $\mathrm{CCl}_{4}$ only & $\mathrm{CCl}_{4} 1 \mathrm{ml} / \mathrm{kg}$ \\
\hline 4 & \multirow{3}{*}{$\begin{array}{c}\text { DIM } \\
+ \\
\mathrm{Cl}_{4}(1 \mathrm{mg} / \mathrm{kg})\end{array}$} & DIM $2.5 \mathrm{mg} / \mathrm{kg}$ \\
\hline 5 & & DIM 5mg/kg \\
\hline 6 & & DIM $10 \mathrm{mg} / \mathrm{kg}$ \\
\hline 7 & \multicolumn{2}{|c|}{ Positive control: silymarin $(10 \mathrm{mg} / \mathrm{kg})$} \\
\hline
\end{tabular}

\section{C}<smiles>c1ccc2c(Cc3c[nH]c4ccccc34)c[nH]c2c1</smiles>

Figure 7. An experimental method for $\mathrm{CCl}_{4}$-induced liver injury model and treatment method. (A) diagram shows sacrifice after 12 and $24 \mathrm{~h}$, (B) table showing treatment doses and groups, (C) The molecular structure of DIM.4.4. Determination of Enzymatic assay.

The blood samples were collected and incubated at room temperature for $30 \mathrm{~min}$ and centrifuged at $3000 \mathrm{rpm}$ for $15 \mathrm{~min}$ at room temperature to separate serum. The serum transaminases (AST and ALT) levels were quantified spectrophotometrically according to the Reitman-Frankel method. 


\subsection{Determination of Enzymatic Assay}

The blood samples were collected and incubated at room temperature for $30 \mathrm{~min}$ and centrifuged at $3000 \mathrm{rpm}$ for $15 \mathrm{~min}$ at room temperature to separate serum. The serum transaminases (AST and ALT) levels were quantified spectrophotometrically according to the Reitman-Frankel method.

\subsection{Measurements of Reduced Glutathione (GSH) and Superoxide Dismutase (SOD) Levels in Liver Tissue}

Liver tissues were homogenized, centrifuged at $12,000 \mathrm{rpm}$ for $15 \mathrm{~min}$ at $4{ }^{\circ} \mathrm{C}$, and the supernatant was collected to measure the levels of reduced GSH and SOD according to the instruction given by the manufacturer (Biovision Incorp., Milpitas, CA, USA). The reduced GSH and SOD were measured spectrophotometrically at 405 and $450 \mathrm{~nm}$, respectively.

\subsection{Measurements of Malondialdehyde (MDA)}

MDA levels in liver tissue homogenates were determined using a commercially available MDA assay Kit (Cell Biolabs, Inc., San Diego, CA, USA), absorbance of the colored complex was measured at a wavelength of $532 \mathrm{~nm}$ by kinetic spectrophotometric. The principle of the assay depends on a colorimetric determination of pink pigment product, derived from the breakdown of polyunsaturated fatty acid TBA (thiobarbituric acid).

\subsection{Measurement of Serum TNF- $\alpha$}

Blood samples were collected and serum was separated at different time intervals after $\mathrm{CCl}_{4}$ injury to the mice. TNF- $\alpha$ levels in the serum were measured by using mouse TNF- $\alpha$ enzyme-linked immunosorbent assay kit (Koma Biotech, Inc., Seoul, Korea), according to the manufacturer's instruction.

\subsection{Liver Histopathology Examination}

Liver tissues were collected and fixed with $4 \%$ paraformaldehyde and embedded in paraffin. Sectioned tissues measuring $5 \mu \mathrm{m}$ in thickness were deparaffinized with xylene and stained with hematoxylin and eosin (H\&E). The histological changes were observed under a light microscope at $100 \times$ and $200 \times$ magnification. Live images were captured and the area of necrosis foci was measured in randomly chosen five areas using image analysis software (Leica Application Suite Version 3.6, Leica Microsystem, Heerbrugg, Switzerland).

\subsection{Microscopic Detection of Reactive Oxygen Species}

Cryosections from snap-frozen liver $(5 \mu \mathrm{m})$ tissues were prepared. In situ ROS detection was performed as described by Lehwald et al., [68] using dihydroethidium (DHE; Invitrogen, Carlsbad, CA, USA). Briefly, cryosections were stained with $5 \mu \mathrm{M}$ DHE for $30 \mathrm{~min}$ and dyed for nucleus by DAPI, mounted by anti-fluorescence quenching sealing tablets in dark at room temperature and observed under a fluorescence microscope (Axioskop 2 Plus, Carls Zeiss, Gottingen, Germany).

\subsection{Western Blot Analysis}

Liver tissues were homogenized with lysis buffer (Intone Biotechnology, Seoul, Korea) supplemented with phosphatase-1 inhibitor cocktail (Sigma, St. Louis, MO, USA) on ice. Tissue homogenates were centrifuged at $13,000 \mathrm{rpm}$ for $30 \mathrm{~min}$ at $4{ }^{\circ} \mathrm{C}$, and supernatants were collected for Western blot analysis. Protein concentration was quantified with Bradford assay (Bio-Rad, Hercules, CA, USA), and proteins were denatured by heating at $95{ }^{\circ} \mathrm{C}$. The denatured proteins were subjected to SDS-PAGE and transferred to the PVDF membrane (Bio-Rad, Hercules, CA, USA). After blocking the membrane with $5 \%$ skimmed milk for $1 \mathrm{~h}$ at room temperature, the blot was incubated either overnight at $4{ }^{\circ} \mathrm{C}$ or $1 \mathrm{~h}$ at room temperature with primary antibodies for anti-mouse actin (1:3000, Sigma), anti-rabbit caspase-3, caspase-9, TNF- $\alpha$, COX-2 (1:1000, Cell Signaling, Danvers, MA, USA), anti-rabbit 
iNOS, Copper, zinc superoxide dismutase (Cu/Zn SOD), HO-1, CYP2E1 (1:1500, Enzo Life Science, Inc., USA), anti-rabbit Bax, Interleukin-1 $\beta$ (IL-1 $\beta$ ), Interleukin-6 (IL-6), NF-kB (p65) and NRF2 (1:1000, Santa Cruz, Dallas, TX, USA), anti-rabbit B-cell lymphoma 2 (Bcl2) (1:1000, Bioworld Tech. Inc., Minneapolis, MN, USA). The membranes were washed and incubated with HRP-conjugated goat anti-mouse or anti-rabbit secondary antibodies. Protein expression was detected using a chemiluminescent detection kit (Millipore Corp., Billercia, MA, USA).

\subsection{Statistical Analysis}

All the experimental data are shown as the means \pm standard deviation (SD). Statistical significance of differences at different time duration (12 and $24 \mathrm{~h}$ ) was calculated with one-way ANOVA followed by unpaired student's test using Prism 7 software (GraphPad Software, San Diego, CA, USA). The $p$ values $<0.05,0.01,0.001$ were considered to be statistically significant.

\section{Conclusions}

Based on results, it was apparent that $\mathrm{CCl}_{4}$ administration induced liver damage by disrupting the morphology of the liver, increasing the serum ALT and AST levels, and inducing inflammatory response and oxidative stress promoting apoptosis. DIM has shown antioxidative, anti-inflammatory and anti-apoptotic abilities, reduced serum ALT and AST thereby ameliorate $\mathrm{CCl}_{4}$-induced liver injury by inhibiting oxidative stress (Figure 8). These outcomes suggest that DIM possesses therapeutic potential against $\mathrm{CCl}_{4}$-induced liver injury.

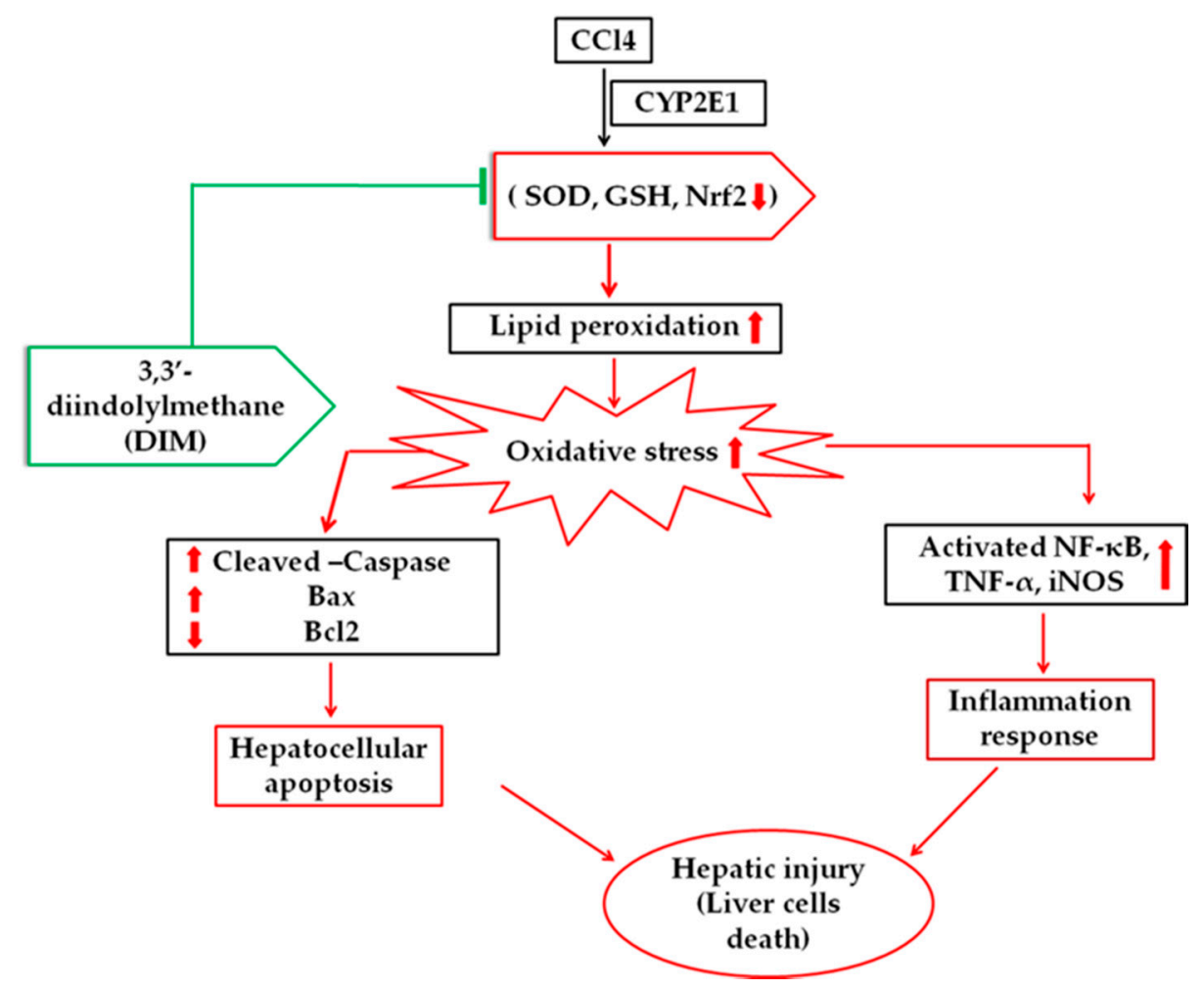

Figure 8. A schematic diagram of the proposed mechanisms by which DIM inhibits $\mathrm{CCl}_{4}$-induced oxidative stress, reduces inflammatory response and inhibits apoptosis by regulating oxidative stress and caspase-3,9/Bax/Bcl2 pathways. In the figure downward red arrow shows $\mathrm{CCl}_{4}$ - induced liver injury decreases antioxidants ability (SOD, GSH, Nrf2) and anti-apoptotic proteins levels Bcl2 whereas upward red arrow shows increased inflammatory responses, oxidative stress and apoptotic proteins, which were altered by DIM pretreatment. 
Supplementary Materials: Supplementary materials can be found at http://www.mdpi.com/1422-0067/21/6/2048/ s1. Figure S1: Effects of DIM on histopathological changes of liver tissues, showing cellular infiltration.

Author Contributions: S.M. and Y.J.J. conceived and designed the experiments; Y.J.J. acted as the principal investigator and provided technical guidance for all aspects of the project. S.M. and L.C. experimented and interpreted the results with assistance from H.B.S., histological assistance provided from K.Y.J. S.M. wrote the manuscript. All authors read and approved the final manuscript for publication.

Funding: This research was supported by research grants from the Research institute of Clinical Medicine of Chonbuk National University, Biomedical Research Institute of Chonbuk National University Hospital.

Conflicts of Interest: The authors declare no conflict of interest. The funders had no role in the design of the study; in the collection, analyses, or interpretation of data; in the writing of the manuscript, or in the decision to publish the results.

\section{Abbreviations}

$\begin{array}{ll}\text { DIM } & \text { 3,3'-Diindolylmethane } \\ \mathrm{CCl}_{4} & \text { carbon tetrachloride } \\ \text { ROS } & \text { reactive oxygen species } \\ \text { TNF- } \alpha & \text { tumor necrosis factor- } \alpha \\ \text { CYP2E1 } & \text { cytochrome P450 2E1 } \\ \text { Nrf2 } & \text { nuclear factor erythroid 2-related factor } 2 \\ \text { NF-kB } & \text { nuclear factor kappa B } \\ \text { HO-1 } & \text { heme oxygenase } \\ \text { AST } & \text { aspartate aminotransferase } \\ \text { ALT } & \text { alanine aminotransferase } \\ \text { GSH } & \text { Glutathione } \\ \text { MDA } & \text { Malondialdehyde } \\ \text { DHE } & \text { Dihydroethidium } \\ \text { SOD } & \text { Superoxide dismutase } \\ \text { Cu/ZnSOD } & \text { Copper, zinc superoxide dismutase } \\ \text { COX-2 } & \text { Cyclooxygenase-2 } \\ \text { iNOS } & \text { Inducible nitric oxide synthase } \\ \text { IL-6 } & \text { Interleukin-6 } \\ \text { IL-1 } \beta & \text { Interleukin-1 } \beta \\ \text { Bcl2 } & \text { B-cell lymphoma 2 } \\ \text { Bax } & \text { Bcl2 associated X protein } \\ \end{array}$

\section{References}

1. Taub, R. Liver regeneration: From myth to mechanism. Nat. Rev. Mol. Cell Biol. 2004, 5, 836. [CrossRef]

2. Risal, P.; Hwang, P.H.; Yun, B.S.; Yi, H.K.; Cho, B.H.; Jang, K.Y.; Jeong, Y.J. Hispidin analogue davallialactone attenuates carbon tetrachloride-induced hepatotoxicity in mice. J. Nat. Prod. 2012, 75, 1683-1689. [CrossRef] [PubMed]

3. Bernal, W.; Auzinger, G.; Dhawan, A.; Wendon, J. Acute liver failure. Lancet 2010, 376, 190-201. [CrossRef]

4. Zhan, Y.; Wang, Z.; Yang, P.; Wang, T.; Xia, L.; Zhou, M.; Wang, Y.; Wang, S.; Hua, Z.; Zhang, J. Adenosine $5^{\prime}$-monophosphate ameliorates D-galactosamine/lipopolysaccharide-induced liver injury through an adenosine receptor-independent mechanism in mice. Cell Death Dis. 2014, 5, e985. [CrossRef] [PubMed]

5. Ren, F.; Zhang, L.; Zhang, X.; Shi, H.; Wen, T.; Bai, L.; Zheng, S.; Chen, Y.; Chen, D.; Li, L.; et al. Inhibition of glycogen synthase kinase 3 beta promotes autophagy to protect mice from acute liver failure mediated by peroxisome proliferator-activated receptor alpha. Cell Death Dis. 2016, 7, e2151. [CrossRef]

6. Busbee, P.B.; Nagarkatti, M.; Nagarkatti, P.S. Natural indoles, indole-3-carbinol (I3C) and 3,3'-diindolylmethane (DIM), attenuate staphylococcal enterotoxin B-mediated liver injury by downregulating miR-31 expression and promoting caspase-2-mediated apoptosis. PLoS ONE 2015, 10, e0118506. [CrossRef]

7. Li, S.; Tan, H.-Y.; Wang, N.; Zhang, Z.-J.; Lao, L.; Wong, C.-W.; Feng, Y. The role of oxidative stress and antioxidants in liver diseases. Int. J. Mol. Sci. 2015, 16, 26087-26124. [CrossRef] 
8. Xu, D.; Xu, M.; Jeong, S.; Qian, Y.; Wu, H.; Xia, Q.; Kong, X. The Role of Nrf2 in Liver Disease: Novel Molecular Mechanisms and Therapeutic Approaches. Front. Pharmacol. 2019, 9, 1428. [CrossRef]

9. Medina, J.; Moreno-Otero, R. Pathophysiological basis for antioxidant therapy in chronic liver disease. Drugs 2005, 65, 2445-2461. [CrossRef]

10. Dey, A.; Lakshmanan, J. The role of antioxidants and other agents in alleviating hyperglycemia mediated oxidative stress and injury in liver. Food Funct. 2013, 4, 1148-1184. [CrossRef]

11. Mallikarjuna, K.; Shanmugam, K.R.; Nishanth, K.; Wu, M.C.; Hou, C.W.; Kuo, C.H.; Reddy, K.S. Alcohol-induced deterioration in primary antioxidant and glutathione family enzymes reversed by exercise training in the liver of old rats. Alcohol 2010, 44, 523-529. [CrossRef]

12. Alam, J.; Stewart, D.; Touchard, C.; Boinapally, S.; Choi, A.M.; Cook, J.L. Nrf2, a Cap'n'Collar transcription factor, regulates induction of the heme oxygenase-1 gene. J. Biol. Chem. 1999, 274, 26071-26078. [CrossRef]

13. Gupte, A.A.; Lyon, C.J.; Hsueh, W.A. Nuclear factor (erythroid-derived 2)-like-2 factor (Nrf2), a key regulator of the antioxidant response to protect against atherosclerosis and nonalcoholic steatohepatitis. Curr. Diabetes Rep. 2013, 13, 362-371. [CrossRef]

14. Vomund, S.; Schäfer, A.; Parnham, M.J.; Brüne, B.; von Knethen, A. Nrf2, the master regulator of anti-oxidative responses. Int. J. Mol. Sci. 2017, 18, 2772. [CrossRef]

15. Chowdhry, S.; Nazmy, M.H.; Meakin, P.J.; Dinkova-Kostova, A.T.; Walsh, S.V.; Tsujita, T.; Dillon, J.F.; Ashford, M.L.J.; Hayes, J.D. Loss of Nrf2 markedly exacerbates nonalcoholic steatohepatitis. Free Radic. Biol. Med. 2010, 48, 357-371. [CrossRef]

16. Ramadori, P.; Drescher, H.; Erschfeld, S.; Fragoulis, A.; Kensler, T.W.; Wruck, C.J.; Cubero, F.J.; Trautwein, C.; Streetz, K.L.; Kroy, D.C. Genetic Nrf2 overactivation inhibits the deleterious effects induced by hepatocyte-specific c-met deletion during the progression of NASH. Oxid. Med. Cell. Longev. 2017, 2017, 3420286. [CrossRef]

17. Lee, C.H.; Park, S.W.; Kim, Y.S.; Kang, S.S.; Kim, J.A.; Lee, S.H.; Lee, S.M. Protective mechanism of glycyrrhizin on acute liver injury induced by carbon tetrachloride in mice. Biol. Pharm. Bull. 2007, 30, 1898-1904. [CrossRef]

18. Fujii, T.; Fuchs, B.C.; Yamada, S.; Lauwers, G.Y.; Kulu, Y.; Goodwin, J.M.; Lanuti, M.; Tanabe, K.K. Mouse model of carbon tetrachloride induced liver fibrosis: Histopathological changes and expression of CD133 and epidermal growth factor. BMC Gastroenterol. 2010, 10, 79. [CrossRef]

19. Edwards, M.J.; Keller, B.J.; Kauffman, F.C.; Thurman, R.G. The Involvement of Kupffer Cells in Carbon Tetrachloride Toxicity. Toxicol. Appl. Pharmacol. 1993, 119, 275-279. [CrossRef]

20. Decker, K. Biologically active products of stimulated liver macrophages (Kupffer cells). Eur. J. Biochem. 1990, 192, 245-261. [CrossRef]

21. Risal, P.; Park, B.H.; Cho, B.H.; Kim, J.C.; Jeong, Y.J. Overexpression of peptidyl-prolyl isomerase Pin1 attenuates hepatocytes apoptosis and secondary necrosis following carbon tetrachloride-induced acute liver injury in mice. Pathol. Int. 2012, 62, 8-15. [CrossRef]

22. Lee, H.-Y.; Kim, S.-W.; Lee, G.-H.; Choi, M.-K.; Jung, H.-W.; Kim, Y.-J.; Kwon, H.-J.; Chae, H.-J. Turmeric extract and its active compound, curcumin, protect against chronic CCl4-induced liver damage by enhancing antioxidation. BMC Complement. Altern. Med. 2016, 16, 316. [CrossRef]

23. McGuire, K.P.; Ngoubilly, N.; Neavyn, M.; Lanza-Jacoby, S. 3,3'-diindolylmethane and paclitaxel act synergistically to promote apoptosis in HER2/Neu human breast cancer cells. J. Surg. Res. 2006, 132, 208-213. [CrossRef]

24. Luo, Q.; Yang, A.; Cao, Q.; Guan, H. 3,3'-Diindolylmethane protects cardiomyocytes from LPS-induced inflammatory response and apoptosis. BMC Pharmacol. Toxicol. 2018, 19, 71. [CrossRef]

25. Tomar, S.; Nagarkatti, M.; Nagarkatti, P.S. 3,3'-Diindolylmethane attenuates LPS-mediated acute liver failure by regulating miRNAs to target IRAK4 and suppress Toll-like receptor signalling. Br. J. Pharmacol. 2015, 172, 2133-2147. [CrossRef]

26. Xia, Z.-E.; Xi, J.-L.; Shi, L. 3,3'-Diindolylmethane ameliorates renal fibrosis through the inhibition of renal fibroblast activation in vivo and in vitro. Renal Fail. 2018, 40,447-454. [CrossRef]

27. Kaplowitz, N. Mechanisms of liver cell injury. J. Hepatol. 2000, 32, 39-47. [CrossRef]

28. Reyes-Gordillo, K.; Segovia, J.; Shibayama, M.; Vergara, P.; Moreno, M.G.; Muriel, P. Curcumin protects against acute liver damage in the rat by inhibiting NF-kappaB, proinflammatory cytokines production and oxidative stress. Biochim. Biophys. Acta 2007, 1770, 989-996. [CrossRef] 
29. Cengiz, N.; Kavak, S.; Güzel, A.; Ozbek, H.; Bektaş, H.; Him, A.; Erdoğan, E.; Balahoroğlu, R. Investigation of the hepatoprotective effects of Sesame (Sesamum indicum L.) in carbon tetrachloride-induced liver toxicity. J. Membr. Biol. 2013, 246, 1-6. [CrossRef]

30. Ashok, B.T.; Chen, Y.G.; Liu, X.; Garikapaty, V.P.; Seplowitz, R.; Tschorn, J.; Roy, K.; Mittelman, A.; Tiwari, R.K. Multiple molecular targets of indole-3-carbinol, a chemopreventive anti-estrogen in breast cancer. Eur. J. Cancer Prev. Off. J. Eur. Cancer Prev. Organ. ECP 2002, 11 (Suppl. 2), S86-S93.

31. Tahir, M.; Sultana, S. Chrysin modulates ethanol metabolism in wistar rats: A promising role against organ toxicities. Alcohol Alcoholism 2011, 46, 383-392. [CrossRef]

32. Slater, T.F.; Cheeseman, K.H.; Ingold, K.U. Carbon tetrachloride toxicity as a model for studying free-radical mediated liver injury. Philos.Trans. R. Soc. Lond. Ser. B Biol. Sci. 1985, 311, 633-645. [CrossRef]

33. Wunjuntuk, K.; Kettawan, A.; Charoenkiatkul, S.; Rungruang, T. Parboiled germinated brown rice protects against CCl4-Induced oxidative stress and liver injury in rats. J. Med. Food 2016, 19, 15-23. [CrossRef]

34. Al-Rasheed, N.; Faddah, L.; Al-Rasheed, N.; Bassiouni, Y.A.; Hasan, I.H.; Mahmoud, A.M.; Mohamad, R.A.; Yacoub, H.I. Protective effects of silymarin, alone or in combination with chlorogenic acid and/or melatonin, against carbon tetrachloride-induced hepatotoxicity. Pharmacogn. Mag. 2016, 12, S337-S345. [CrossRef]

35. Dai, Y.; Cederbaum, A.I. Inactivation and degradation of human cytochrome P4502E1 by CCl4 in a transfected HepG2 cell line. J. Pharmacol. Exp. Ther. 1995, 275, 1614-1622.

36. Ai, G.; Liu, Q.; Hua, W.; Huang, Z.; Wang, D. Hepatoprotective evaluation of the total flavonoids extracted from flowers of Abelmoschus manihot (L.) Medic: In vitro and in vivo studies. J. Ethnopharmacol. 2013, 146, 794-802. [CrossRef]

37. Zhang, W.; Dong, Z.; Chang, X.; Zhang, C.; Rong, G.; Gao, X.; Zeng, Z.; Wang, C.; Chen, Y.; Rong, Y.; et al. Protective effect of the total flavonoids from Apocynum venetum L. on carbon tetrachloride-induced hepatotoxicity in vitro and in vivo. J. Physiol. Biochem. 2018, 74, 301-312. [CrossRef]

38. Plaa, G.L. Chlorinated Methanes and Liver Injury: Highlights of the Past 50 Years. Annu. Rev. Pharmacol. Toxicol. 2000, 40, 43-65. [CrossRef]

39. Ismail, A.F.M.; Salem, A.A.M.; Eassawy, M.M.T. Hepatoprotective effect of grape seed oil against carbon tetrachloride induced oxidative stress in liver of $\gamma$-irradiated rat. J. Photochem. Photobiol. B Biol. 2016, 160, 1-10. [CrossRef]

40. Ighodaro, O.M.; Akinloye, O.A. First line defence antioxidants-superoxide dismutase (SOD), catalase (CAT) and glutathione peroxidase (GPX): Their fundamental role in the entire antioxidant defence grid. Alex. J. Med. 2018, 54, 287-293. [CrossRef]

41. Nordberg, J.; Arnér, E.S.J. Reactive oxygen species, antioxidants, and the mammalian thioredoxin system1 1This review is based on the licentiate thesis "Thioredoxin reductase-Interactions with the redox active compounds 1-chloro-2,4-dinitrobenzene and lipoic acid" by Jonas Nordberg, 2001, Karolinska Institute, Stockholm, ISBN 91-631-1064-4. Free Radic. Biol. Med. 2001, 31, 1287-1312. [CrossRef]

42. Nielsen, F.; Mikkelsen, B.B.; Nielsen, J.B.; Andersen, H.R.; Grandjean, P. Plasma malondialdehyde as biomarker for oxidative stress: Reference interval and effects of life-style factors. Clin. Chem. 1997, 43, 1209-1214. [CrossRef]

43. Levings, D.C.; Wang, X.; Kohlhase, D.; Bell, D.A.; Slattery, M. A distinct class of antioxidant response elements is consistently activated in tumors with NRF2 mutations. Redox Biol. 2018, 19, 235-249. [CrossRef]

44. Kaspar, J.W.; Niture, S.K.; Jaiswal, A.K. Nrf2:INrf2 (Keap1) signaling in oxidative stress. Free Radic. Biol. Med. 2009, 47, 1304-1309. [CrossRef]

45. Ma, Q.; He, X. Molecular basis of electrophilic and oxidative defense: Promises and perils of Nrf2. Pharmacol. Rev. 2012, 64, 1055-1081. [CrossRef]

46. Abdel Moneim, A.E. Indigofera oblongifolia prevents lead acetate-induced hepatotoxicity, oxidative stress, fibrosis and apoptosis in rats. PLoS ONE 2016, 11, e0158965. [CrossRef]

47. Cai, Z.; Lou, Q.; Wang, F.; Li, E.; Sun, J.; Fang, H.; Xi, J.; Ju, L. N-acetylcysteine protects against liver injure induced by carbon tetrachloride via activation of the Nrf2/HO-1 pathway. Int. J. Clin. Exp. Pathol. 2015, 8, $8655-8662$.

48. Ji, S.; Li, Z.; Song, W.; Wang, Y.; Liang, W.; Li, K.; Tang, S.; Wang, Q.; Qiao, X.; Zhou, D.; et al. Bioactive constituents of glycyrrhiza uralensis (Licorice): Discovery of the effective components of a traditional herbal medicine. J. Nat. Prod. 2016, 79, 281-292. [CrossRef] 
49. Chen, S.; Zou, L.; Li, L.; Wu, T. The protective effect of glycyrrhetinic acid on carbon tetrachloride-induced chronic liver fibrosis in mice via upregulation of Nrf2. PLOS ONE 2013, 8, e53662. [CrossRef]

50. Cao, Y.-W.; Jiang, Y.; Zhang, D.-Y.; Wang, M.; Chen, W.-S.; Su, H.; Wang, Y.-T.; Wan, J.-B. Protective effects of penthorum chinense pursh against chronic ethanol-induced liver injury in mice. J. Ethnopharmacol. 2015, 161, 92-98. [CrossRef]

51. Wang, M.; Zhang, X.-J.; Feng, R.; Jiang, Y.; Zhang, D.-Y.; He, C.; Li, P.; Wan, J.-B. Hepatoprotective properties of Penthorum chinense Pursh against carbon tetrachloride-induced acute liver injury in mice. Chin. Med. 2017, 12, 32. [CrossRef]

52. Sass, G.; Heinlein, S.; Agli, A.; Bang, R.; Schümann, J.; Tiegs, G. Cytokine expression in three mouse models of experimental hepatitis. Cytokine 2002, 19, 115-120. [CrossRef]

53. Ning, C.; Gao, X.; Wang, C.; Huo, X.; Liu, Z.; Sun, H.; Yang, X.; Sun, P.; Ma, X.; Meng, Q.; et al. Hepatoprotective effect of ginsenoside Rg1 from Panax ginseng on carbon tetrachloride-induced acute liver injury by activating Nrf2 signaling pathway in mice. Environ. Toxicol. 2018, 33, 1050-1060. [CrossRef]

54. Germoush, M.O.; Othman, S.I.; Al-Qaraawi, M.A.; Al-Harbi, H.M.; Hussein, O.E.; Al-Basher, G.; Alotaibi, M.F.; Elgebaly, H.A.; Sandhu, M.A.; Allam, A.A.; et al. Umbelliferone prevents oxidative stress, inflammation and hematological alterations, and modulates glutamate-nitric oxide-cGMP signaling in hyperammonemic rats. Biomed. Pharmacother. 2018, 102, 392-402. [CrossRef]

55. Utaipan, T.; Suksamrarn, A.; Kaemchantuek, P.; Chokchaisiri, R.; Stremmel, W.; Chamulitrat, W.; Chunglok, W. Diterpenoid trigonoreidon B isolated from Trigonostemon reidioides alleviates inflammation in models of LPS-stimulated murine macrophages and inflammatory liver injury in mice. Biomed. Pharmacother. 2018, 101, 961-971. [CrossRef]

56. Kiso, K.; Ueno, S.; Fukuda, M.; Ichi, I.; Kobayashi, K.; Sakai, T.; Fukui, K.; Kojo, S. The Role of Kupffer Cells in Carbon Tetrachloride Intoxication in Mice. Biol. Pharm. Bull. 2012, 35, 980-983. [CrossRef]

57. Korhonen, R.; Lahti, A.; Kankaanranta, H.; Moilanen, E. Nitric Oxide Production and Signaling in Inflammation. Curr. Drug Targets Inflamm. Allergy 2005, 4, 471-479. [CrossRef]

58. Shi, J.; Aisaki, K.; Ikawa, Y.; Wake, K. Evidence of hepatocyte apoptosis in rat liver after the administration of carbon tetrachloride. Am. J. Pathol. 1998, 153, 515-525. [CrossRef]

59. Aram, G.; Potter, J.J.; Liu, X.; Wang, L.; Torbenson, M.S.; Mezey, E. Deficiency of nicotinamide adenine dinucleotide phosphate, reduced form oxidase enhances hepatocellular injury but attenuates fibrosis after chronic carbon tetrachloride administration. Hepatology 2009, 49, 911-919. [CrossRef]

60. Guo, X.-L.; Liang, B.; Wang, X.-W.; Fan, F.-G.; Jin, J.; Lan, R.; Yang, J.-H.; Wang, X.-C.; Jin, L.; Cao, Q. Glycyrrhizic acid attenuates $\mathrm{CCl}_{4}$-induced hepatocyte apoptosis in rats via a p53-mediated pathway. World J. Gastroenterol. 2013, 19, 3781-3791. [CrossRef]

61. Czabotar, P.E.; Lessene, G.; Strasser, A.; Adams, J.M. Control of apoptosis by the BCL-2 protein family: Implications for physiology and therapy. Nat. Rev. Mol. Cell Biol. 2014, 15, 49-63. [CrossRef] [PubMed]

62. Shirali, S.; Aghaei, M.; Shabani, M.; Fathi, M.; Sohrabi, M.; Moeinifard, M. Adenosine induces cell cycle arrest and apoptosis via cyclinD1/Cdk4 and Bcl-2/Bax pathways in human ovarian cancer cell line OVCAR-3. Tumor Biol. 2013, 34, 1085-1095. [CrossRef] [PubMed]

63. Sun, Y.; Lin, Y.; Li, H.; Liu, J.; Sheng, X.; Zhang, W. 2,5-Hexanedione induces human ovarian granulosa cell apoptosis through BCL-2, BAX, and CASPASE-3 signaling pathways. Arch. Toxicol. 2012, 86, 205-215. [CrossRef] [PubMed]

64. Lee, J.S.; Jung, W.-K.; Jeong, M.H.; Yoon, T.R.; Kim, H.K. Sanguinarine Induces Apoptosis of HT-29 Human Colon Cancer Cells via the Regulation of Bax/Bcl-2 Ratio and Caspase-9-Dependent Pathway. Int. J. Toxicol. 2012, 31, 70-77. [CrossRef]

65. Spampanato, C.; De Maria, S.; Sarnataro, M.; Giordano, E.; Zanfardino, M.; Baiano, S.; Cartenì, M.; Morelli, F. Simvastatin inhibits cancer cell growth by inducing apoptosis correlated to activation of Bax and down-regulation of BCL-2 gene expression. Int. J. Oncol. 2012, 40, 935-941. [CrossRef]

66. Mahmoodzadeh, Y.; Mazani, M.; Rezagholizadeh, L. Hepatoprotective effect of methanolic Tanacetum parthenium extract on CCl4-induced liver damage in rats. Toxicol. Rep. 2017, 4, 455-462. [CrossRef] 
67. Niu, X.; Liu, F.; Li, W.; Zhi, W.; Yao, Q.; Zhao, J.; Yang, G.; Wang, X.; Qin, L.; He, Z. Hepatoprotective effect of fraxin against carbon tetrachloride-induced hepatotoxicity in vitro and in vivo through regulating hepatic antioxidant, inflammation response and the MAPK-NF- KB signaling pathway. Biomed. Pharmacother. 2017, 95, 1091-1102. [CrossRef]

68. Lehwald, N.; Tao, G.-Z.; Jang, K.Y.; Sorkin, M.; Knoefel, W.T.; Sylvester, K.G. Wnt- $\beta$-catenin signaling protects against hepatic ischemia and reperfusion injury in mice. Gastroenterology 2011, 141, 707-718.e5. [CrossRef]

(C) 2020 by the authors. Licensee MDPI, Basel, Switzerland. This article is an open access article distributed under the terms and conditions of the Creative Commons Attribution (CC BY) license (http://creativecommons.org/licenses/by/4.0/). 